\title{
HELLP Sendromu
}

Sayın Editör,

Türkiye Acil Tıp Dergisi 13. cilt 2. sayı derginizin editöre mektup kısmında Karakuş ve arkadaşlarının "Sevkli ve Ön Tanılı Hastalara Dikkat Etmeli! Gebe Uterus Rüptürü Olgusu" isimli yazıyı ilgiyle okudum. Bazı noktalar ilgimi çekti ve bunları da sizinle paylaşmak istedim.

Olguda kırk yaşında 26 haftalık bir gebenin evde solunumsal ve kardiyak arrest olması nedeniyle entübe edilip resüsitasyon yapılıp yoğun bakım ihtiyacı nedeniyle acil servise getirilmesinden bahsedilmektedir.

112 acil müdahale ekibinin yakınlarından aldığı anamnezde sekiz saat öncesinde başlayan kendini kötü hissetme, nefes darlığı, baygınlık, aşırı terleme şikâyetleri olduğu ifade ediliyor. Acil serviste değerlendirilmesinde GKS 3, pupiller dilate, ışık refleksi ve spontan solunumu olmadığı, vitallerinde de arteryel tansiyonun $50 / 30 \mathrm{mmHg}$, beyaz küre $60600 / \mathrm{mm}^{3}$ hemoglobin 5.2 g/dl, AST 138 U/L, ALT 80 U/L, D-dimer >10000 ng/ml, glukoz $265 \mathrm{mg} / \mathrm{dl}$, potasyum $5.7 \mathrm{mmol} / \mathrm{L}$ olduğu belirtilmiştir. EKO ve göğüs tomografisinin normal olduğu yatak başı ultrasonografisinde de batın içi serbest sıvı tespit edildiği anlatılmıştır. Sonrasında da ameliyat edildiği ve eski sezaryen hattından uterus rüptürü tespit edildiği, ameliyatta arrest olması sonrası tekrar resüsitasyon yapıldığı fakat hastanın kaybedildiği anlatılmıştır.

Bu yazı incelendiğinde bazı noktalar dikkatimi çekti. Uterus rüptürü daha çok gebelik haftası ilerlemiş, doğum kontraksiyonları başlamış ya da doğum esnasında ortaya çıkabilen klinik bir durumdur. Uterus rüptürü gebelik haftası ile artan uterus içi basınçla doğru orantılıdır. 40 hafta üzeri gebelikler uterin rüptür riskini artmaktadır. ${ }^{[1,2]} 28$ hafta altında uterus rüptürü olan çok az sayıda olgu bildirilmiştir. Bu olgular da uterus anomalileri ve intrauterin enfeksiyonlarla ilişkilendirilmiştir. ${ }^{[3]}$

Alanda entübe edilip kardiyopulmoner arrest ön tanısıyla getirilen, eski sezeryanı olan 26 haftalık gebe hastada muhtemelen uygulanan resüsitasyona bağlı artan karın içi basınca ikincil olarak gelişen uterus rüptürü sözkonusu olabilir. Yazıda resüsitasyon yapılıp yapılmadığı, ne kadar süreyle yapıldığı, paralizan ve sedatizan ajan verilip verilmediği belirtilmemiştir.

Bunlarla birlikte gebelerde görülen HELLP Sendromu (hemolysis, elevated liver enzymes, low platelets) (hemoliz, karaciğer enzimlerinin yükselmesi, düşük trombosit seviyesi) bu hastada düşünülmelidir. Yazıda trombosit seviyelerinden bahsedilmemekle birlikte karaciğer enzimlerinin yüksekli- ği, hemoglobin değerinin düşüklüğü ve koagulasyon ürünü olan D-dimer'in çok yüksek oluşu HELLP sendromunu akla getirmektedir. ${ }^{[4]}$ Marcq ve ark.nın yaptıkları çalışmada D-dimer HELLP sendromlu hastalarda sadece preeklampsili hastalara göre anlamalı olarak yüksek çıkmıştır. ${ }^{[4]}$

Sevkli ve ön tanılı hastalara dikkat edilmesi ile ilgili mektubu nedeniyle Karakuş'u önemli bir konuya dikkat çektikleri için kutlarım.

Saygılarımla.

\section{Dr. Mehmet TATLI}

Dr. Lütfi Kırdar Kartal Eğitim ve Araştırma Hastanesi, Acil Tıp Kliniği, İstanbul

\section{Kaynaklar}

1. Kiran TS, Chui YK, Bethel J, Bhal PS. Is gestational age an independent variable affecting uterine scar rupture rates? Eur J Obstet Gynecol Reprod Biol 2006;126:68-71. [CrossRef]

2. Al-Zirqi I, Stray-Pedersen B, Forsén L, Vangen S. Uterine rupture after previous caesarean section. BJOG 2010;117:809-20. [CrossRef]

3. Dabulis SA, McGuirk TD. An unusual case of hemoperitoneum: uterine rupture at 9 weeks gestational age. J Emerg Med 2007;33:285-7. [CrossRef]

4. Marcq G, Beaugrand Dubart L, Tournoys A, Subtil D, Deruelle P. Evaluation of d-dimer as a marker for severity in pregnancies with preeclampsia. [Article in French] Gynecol Obstet Fertil 2012 Oct 22. [Abstract]

\section{Yazarın yanıtı}

Sayın Editör,

Türkiye Acil Tıp Dergisi'nin 2013 yıl 2. sayısında editöre mektup olarak sunduğumuz "Sevkli ve Ön Tanılı Hastalara Dikkat Etmeli! Gebe Uterus Rüptürü Olgusu" başlıklı yazıya atfen yazılan editöre mektup yazısını incelemiş bulunmaktayım. Sayın yazarın merak ettiği konulara cevaben:

Alanda ve dış merkezde resüsitasyon yapılmış ancak süresi bilinmemektedir. Paralizan ve sedatizan ajan verilmemiştir. Trombosit sayısı 203.10^3/ $\mu \mathrm{L}(100,0-300,0)$ olup normal sInırlardadır. Bu nedenle HELLP sendromu tanısı için kullanılan Mississippi kriterleri'ne uymamaktadır. Ancak hastanın diğer mevcut klinik ve değerleri ele alınırsa ayırıı tanıda, karın içi basınç artışına bağlı rüptür ve HELLP sendromuna değindiği için katkılarından dolayı sayın yazara teşekkür ediyorum.

Saygılarımla,

\section{Dr. Ali KARAKUŞ}

Geliş tarihi (Submitted): 18.07.2013 Kabul tarihi (Accepted): 18.07.2013 Online baskı (Published online): 29.07.2013 İletişim (Correspondence): Dr. Mehmet Tatlı. Dr. Lütfi Kırdar Kartal Eğitim ve Araştırma Hastanesi, Acil Tıp Kliniği, 34880 Cevizli / Kartal, İstanbul, Turkey. e-posta (e-mail): drmehmettatli@gmail.com 